\title{
REALIZACJA POTRZEB SPOLECZNYCH PACJENTÓW W OBRĘBIE SZPITALA GERIATRYCZNEGO
}

Streszczenie. W artykule przedstawiono uwarunkowania funkcjonalne i przestrzenne szpitali geriatrycznych oraz ich wpływ na realizację potrzeb społecznych pacjentów.

Przyjęto założenie, że istnieje szereg uwarunkowań przestrzennych, które mogą stać się elementami wspierającymi aktywność osób starszych w szpitalach geriatrycznych. W związku z tym przeprowadzono badania jakościowe na wybranych przykładach polskich i zagranicznych, w celu wskazania rekomendowanych rozwiązań w zakresie lokalizacji, ukształtowania samego budynku oraz wytypowanych stref funkcjonalnych służących pacjentom. Przedstawienie potrzeb społecznych stanowiło punkt wyjścia do przyjęcia konkretnych rozwiązań projektowych.

Slowa kluczowe: szpitalnictwo geriatryczne, badania interdyscyplinarne, osoby starsze.

\section{Wprowadzenie}

Wzrost populacji osób starszych spowodował, że przed opieką zdrowotną stoją nowe wyzwania, związane między innymi z zapewnieniem im odpowiedniej opieki medycznej. Według Raportu „Problemy zdrowia publicznego w kontekście starzenia się populacji Polski" (Barcikowska 2006: 203-211) osoby starsze stanowią w Polsce blisko 13\% ogółu populacji, jednak w znacznie większym stopniu niż pozostałe grupy wiekowe korzystają ze świadczeń zdrowotnych. Wskaźniki hospitalizacji w tej grupie wiekowej według danych Państwowego Zakładu Higieny są 2-3 krotnie wyższe niż dla ogółu ludności.

W związku z tym niezbędna jest wiedza o problemach wieku podeszłego, aby racjonalnie zaplanować odpowiednią opiekę nad osobami starszymi. Potrzeby osób starszych to między innymi stworzenie przyjaznego środowiska przestrzennego związanego z ochroną zdrowia - to jedno z kluczowych wyzwań współczesnej architektury szpitali, szczególnie oddziałów i szpitali geriatrycznych. Obiekty te nie są w pełni przygotowane do spełniania specyficznych potrzeb pacjenta geriatrycznego. Opieka medyczna nie uwzględnia odrębności starszych pacjentów - szpitale nie są przygotowane pod względem funkcjonalnym

* Dr, inż. arch., Wydział Architektury, Politechnika Śląska, Gliwice.

${ }^{* *}$ Dr, inż. arch., Wydział Architektury, Politechnika Śląska, Gliwice. 
i formalnym na ich przyjęcie. Opiece nad osobą starszą nie sprzyjają również uwarunkowania psychospołeczne: towarzyszy im brak poczucia bezpieczeństwa, lęk, brak akceptacji w społeczeństwie.

\section{Specyficzne wymagania pacjenta geriatrycznego}

Pacjent geriatryczny to osoba, która ukończyła 60 rok życia, cierpiąca na różnego rodzaju dolegliwości zdrowotne. Do głównych problemów geriatrycznych należą między innymi: zespoły otępienne, zespoły depresyjne i lękowe, zaburzenia zachowania, dolegliwości kardiologiczne, nietrzymanie moczu, upadki i zasłabnięcia, zmiany zwyrodnieniowe stawów, zaburzenia endokrynologiczne, zawroty głowy, a także zaburzenia równowagi (Derejczyk 2005: 6783). U pacjentów geriatrycznych pojawiają się trudności zdrowotne, które według uproszczonego podziału możemy zakwalifikować jako somatyczne i psychiczne. Problemy zdrowotne i pielęgnacyjne pacjentów w starszym wie$\mathrm{ku}$, często przewlekle chorych, rodzą szereg wymagań, które powodują konieczność specyficznego podejścia do projektowania szpitali geriatrycznych, w tym przestrzeni społecznych występujących w ich obrębie. Należy wziąc pod uwagę deficyty w samodzielności dotyczące wykonywania czynności codziennych, do tego dochodzą problemy związane, np. z poczuciem osamotnienia, wyobcowania czy bezużyteczności Osobom starszym towarzyszy często niska samoocena i zaniżone poczucie własnej wartości, trudności w porozumieniu i kontaktach międzyludzkich, lęk o zdrowie i życie własne oraz najbliższych osób, stopniowa utrata poczucia bezpieczeństwa fizycznego i psychicznego, poczucie zagubienia, zwłaszcza w nowych przestrzeniach, występowanie zaburzeń nastroju, skłonności depresyjne.

Opisanie charakterystyki pacjenta geriatrycznego jest zadaniem trudnym. Mianem pacjenta geriatrycznego możemy bowiem określić zarówno osobę, która cierpi na chorobę Alzheimera i jest całkowicie zależna od opiekunów, taką, u której występuje zwyrodnienie stawów i odczuwa znaczne dolegliwości bólowe, ale również taką, u której zdiagnozowano cukrzycę i która jest w pełni samodzielna. Już to krótkie zestawienie wskazuje, iż pod nazwą „pacjent geriatryczny" kryje się wiele stanów psychofizycznych. Można jednak wyodrębnić kilka podstawowych, psychologicznych aspektów funkcjonowania pacjenta geriatrycznego.

Zmiany zwyrodnieniowe osób starszych powodują między innymi zaburzenia rytmu sen-czuwanie decydującego o samopoczuciu i jakości życia osób starszych. U osób starszych potrzeba snu zmniejsza się. Sen (np. u osób z demencją) jest związany nie tylko z porą nocną, a dość charakterystyczną cechą jest skłonność do podsypiania w ciągu dnia. Drzemki te z kolei są przyczyną zmniejszenia 
czasu trwania snu w godzinach nocnych. Utrudnione jest zasypianie. Występują także zaburzenia utrzymania ciągłości snu, czyli częste wybudzenia w ciągu nocy oraz trudności z ponownym zaśnięciem (Toutou 1994). Objawy zaburzenia rytmu okołodobowego i zaburzenia snu łagodzi światło słoneczne (lub sztuczne - ale dostatecznie intensywne).

Osobom starszym często towarzyszy depresyjna choroba zwana sezonowym zaburzeniem afektywnym (SAD), której charakter zmienia się wraz z porami roku. Objawami są senność, zmiany nastroju, brak energii, przejadanie się itp. Mechanizm choroby jest ściśle związany z klimatem świetlnym. Objawy jej zimowej odmiany zwykle ustępują wraz z początkiem lata, by znów pojawić jesienią (Tornington 2007: 81-97). Osoby starsze pozostają często w niedostatecznie oświetlonych pomieszczeniach, nie wychodzą na zewnątrz nawet przez kilka dni i w efekcie są narażone na pogorszenie samopoczucia.

Szczególne znaczenie dla samopoczucia osób starszych (które większość czasu spędzają wewnątrz budynków) ma postrzeganie świata zewnętrznego. Bardzo istotne przy projektowaniu obiektów szpitalnych jest nie tylko zapewnienie wnikania odpowiedniej ilości światła dziennego do pomieszczeń, ale także widok, który rozpościera się z okna. Okno staje się dla osoby starszej swoistym pomostem łączącym ze światem zewnętrznym. Atrakcyjny widok z okna może mieć terapeutyczne i stymulujące działanie na psychikę osób starszych. Najbardziej preferowane są naturalne scenerie: drzew, wody, otwartego krajobrazu itp. (Chalfont 2007). Zauważono, poprzez obserwację osób zamkniętych w pomieszczeniach ich zainteresowanie światem zewnętrznym. Rozmieszczenie okien, jak również mebli we wnętrzu powinno umożliwić obserwowanie codziennych aktywności ze świata zewnętrznego. Okno ma również szczególnie wspierające znaczenie w zakresie orientacji w czasie (pora dnia i roku). Jednocześnie widoki znanych zewnętrznych obrazów ukierunkowują wzrok i stanowią punkty odniesienia we wnętrzu. Przykładem zastosowania stymulującego kontaktu z naturą, poza oknami w pokojach, są ogrody zimowe lub świetlice.

Lęk przed upadkiem w znacznym stopniu powstrzymuje podejmowanie aktywności osób w starszym wieku. By ludzie o osłabionej, w wyniku zmian fizjologicznych lub patologicznych kondycji mogli się pewnie poruszać kontynuując swą dawną aktywność, ważnym jest stosowanie odpowiednich materiałów wykończeniowych podłóg i mebli. Wykończone na wysoki połysk powierzchnie podłóg ograniczają postrzeganie na skutek lustrzanych odbić przedmiotów, a w szczególności opraw oświetleniowych. Przy stosowaniu materiałów wykończeniowych istotna jest zmienność barwy i odpowiedni kontrast przyległych powierzchni. Ze szczególną uwagą należy podchodzić do wyróżniania brzegów płaszczyzn przy zmianie poziomów (np. wyróżnienie kontrastowymi pasami podstopnic schodów w budynku). 
Rozpoznawanie miejsc jest głównym tematem zainteresowania psychologii poznawczej. U osób starszych może dochodzić do zaburzeń w zakresie pamięci krótkotrwałej, co może być powodem stresu, przemęczenia, ogólnej dezorientacji. Zaprojektowanie odpowiedniego systemu informacyjnego jako czytelnego komunikatu, odpowiedniej kolorystyki oraz oświetlenia sztucznego, okien z charakterystycznymi cechami i widokami ma ścisły związek $\mathrm{z}$ rozpoznawaniem miejsc.

\section{Ogólne zasady projektowania szpitala geriatrycznego zgodnie z potrzebami pacjentów geriatrycznych}

W świetle zmian fizycznych towarzyszących starzeniu się (zmiany w zakresie wzroku, zmiany w zakresie słuchu, problemy medyczne, zmiany budowy ciała - mięśni, kości, zmiany funkcji poznawczych), zidentyfikowano liczne elementy projektowe, które mogą wpływać na niezależność funkcjonowania i bezpieczeństwo hospitalizowanych starszych ludzi.

Wiele elementów projektowych pozostaje względnie jednorodnych we wszystkich szpitalach, mogą pojawiać się niewielkie zmiany pod względem powierzchni, ale istnieją również miejsca $\mathrm{w}$ szpitalach które wymagają specyficznych zaleceń.

Podstawowe elementy występujące $\mathrm{w}$ budynku szpitala, odnoszące się do wymogów projektowych skierowanych do osób starszych to (Parke 2007): oświetlenie, kolorystyka, informacyjny system graficzny, posadzki i ściany, hole, drzwi i okna, uchwyty i poręcze, korytarze , pochylnie, schody, akustyka, specjalne umeblowanie, windy, toalety.

Zrozumienie pacjenta geriatrycznego, z wszystkimi jego dysfunkcjami, jest krokiem w stronę stworzenia odpowiedniego środowiska, bezpiecznego, pozwalającego na wykorzystanie możliwości osób starszych, wzmacnianie ich tożsamości.

Dobre oświetlenie $\mathrm{w}$ budynkach szpitalnych pomaga użytkownikom w orientacji, wzmacnia poczucie bezpieczeństwa, np. poprzez możliwość rozpoznawania systemów informacji graficznej, możliwość widzenia rozmówcy jego twarzy. Słabe oświetlenie - zwiększa niepokój, zwiększa ryzyko upadku oraz powoduje, że otoczenie staje się mniej czytelne. Fizjologiczne zmiany wzroku u osób starszych powodują, że potrzebują one dwa razy więcej światła, niż określają to normalne standardy oświetlenia. Jest to szczególnie ważne dla osób z demencją ze względu na zdolność ich mózgu do przetwarzania sygnałów wizualnych - między innymi wyższy poziom oświetlenia wspomaga zachowania racjonalne. 
Kolejnymi elementami wpływającymi na prawidłowe widzenie są odbicie i kontrast. Odblaski dezorientują, dlatego zaleca się stosowanie ogólnego, jednorodnego oświetlenia o stałym natężeniu na sufitach i ścianach, bez stosowania oświetlenia punktowego, np. w postaci reflektorów. Kontrola oświetlenia powinna odbywać się za pomocą czujników ruchu, czasowych wyłączników, wyłączników działających przy odpowiedniej ilości światła dziennego, dlatego zaleca się stosowanie systemów oświetleniowych, które minimalizują również koszty zużycia energii elektrycznej. Optymalne wykorzystanie światła dziennego uzyskujemy poprzez zastosowanie odpowiedniej kolorystyki, która może rozjaśniać pomieszczenia ciemne, ale i blokować nadmierną ilość światła dziennego, co zapobiega stosowaniu żaluzji czy zasłon - które mogą ograniczać kontakt $\mathrm{z}$ otoczeniem.

Kontakt ze światłem dziennym jest bardzo istotny dla pacjentów cierpiących na zaburzenia rytmu okołodobowego i snu - wyjście na zewnątrz w godzinach porannych, nawet $\mathrm{w}$ zachmurzony dzień, wspomaga utrzymanie prawidłowego rytmu dobowego, ale również wywołuje produkcję witaminy D, która ma bezpośredni wpływ na wytrzymałość kości oraz wydajność mięśni.

U osób starszych obserwujemy szereg zmian w funkcjonowaniu wzroku. Starzenie prowadzi do osłabienia wzroku, głównie ze względu na zmiany w soczewce oka, a ludzie starzy często mają problemy ze wzrokiem związane z zaburzeniem percepcji głębi, dezorientacją przestrzenną, zmienioną percepcję kolorów i zmniejszoną zdolnością do postrzegania kontrastów. Osoby starsze mogą mieć zaćmę, zwyrodnienie plamki żółtej, cukrzycę, cierpieć na daltonizm (zwłaszcza mężczyźni) oraz jaskrę. Niewyraźne widzenie i utrata widzenia centralnego i obwodowego są najpoważniejszymi skutkami tych zaburzeń. Zmiany te powodują konieczność zastosowania większej ilości oświetlenia, skutkują zwiększoną wrażliwością na olśnienie, zmniejszeniem pola widzenia, obniżoną wrażliwością na kontrast, zmniejszoną szybkością dostosowywania się do zmian w poziomie oświetlenia, zmniejszoną ostrością widzenia, ograniczeniem percepcji głębi. Zmienia się również percepcja kolorów - osoby starsze są mniej zdolne do rozróżniania nienasyconych (mniej intensywnych) kolorów, takich jak kolory pastelowe. Podczas projektowania środowiska, w którym przebywać będą pacjenci geriatryczni należy pamiętać, że osoby takie inaczej postrzegają swoje otoczenie. W jego zrozumieniu, w zwiększeniu poczucia bezpieczeństwa na pewno pomaga odpowiednie wykorzystanie koloru i kontrastu.

Elementy środowiska istotne dla użytkowników szpitala, np. ważne węzły komunikacyjne, punkty informacji, poczekalnie, należy projektować z zastosowaniem większego kontrastu i odpowiedniego oświetlenia. Przeciwny efekt uzyskujemy stosując mały kontrast, np. przy oznakowaniu pomieszczeń nie przeznaczonych dla pacjentów, a dla personelu (pokoje pracowników, pomieszczenia techniczne, magazyny itp.) - w tym wypadku nie należy stosować mocnej 
kolorystyki i należy unikać kontrastowego zestawiania kolorów. Mniejszy kontrast należy również stosować przy projektowaniu posadzki - przy zmianie koloru podłogi należy robić to stopniowo, ponieważ mocne zróżnicowanie kolorystyczne posadzek może wywoływać wrażenie nierówności, co z kolei prowadzi do niestabilności, zachwiań i niekiedy do upadku. Jeśli chodzi o posadzki w obiektach takich jak szpitale należy unikać stosowania wzorów, deseni, gdyż mogą, szczególnie osobom z demencją, kojarzyć się z dziurami lub przeszkodami. Oczywiście nie stosuje się powierzchni błyszczących.

Możliwość wyjścia na zewnątrz szpitala daje pacjentowi szansę kontaktu ze świeżym powietrzem, słońcem i zielenią - poprawia to samopoczucie, łagodzi stresy - innymi słowy jest niezbędne dla naszego zdrowia fizycznego i psychicznego. Pacjent geriatryczny ma szansę na uzupełnienie niedoborów witaminy $\mathrm{D}$, regulację zegara biologicznego - ten rodzaj aktywności na poziomie nawet piętnastominutowego spaceru dziennie poprawia stan ogólny, między innymi osób z demencją. Dla tej grupy osób, taki rodzaj aktywności ogranicza spadek zdolności poznawczych. Opisywana wcześniej depresja sezonowa również może być ograniczania przez spacer w ciągu dnia, najlepiej w jasne dni. Zaleca się również projektowanie ogrodów z możliwością pielęgnacji roślin, ewentualnie z możliwością ich obserwacji lub po prostu obserwacji aktywności innych, dziennych zmian światła, słońca, chmur, zieleni. Konieczne jest więc stworzenie odpowiednich warunków - bezpiecznego ogrodu z miejscami do siedzenia, czytelnym dojściem do ogrodu lub patio, czy zaprojektowanie bardziej specjalistycznych elementów zagospodarowania otoczenia budynku, takich jak np. ścieżki sensoryczne.

Dezorientacja jest powszechnym doświadczeniem pacjenta geriatrycznego w obcym środowisku szpitalnym - wynika to ze zmniejszonej zdolności dostosowania się do nowego miejsca, osłabienia pamięci i zdolności uczenia się. Dlatego istotnym elementem prawidłowego funkcjonowania pacjenta geriatrycznego w szpitalu jest zaprojektowanie czytelnego systemu graficznego. Jedynie konsekwentne działanie w tej dziedzinie pozwala na odczytywanie znaków graficznych. Problemem istniejących systemów identyfikacji wizualnej w szpitalach (ale również w innych ośrodkach dla osób starszych) bywa chaos, nadmiar oznaczeń graficznych. Rozwiązaniem problemu czytelnej informacji graficznej w szpitalach jest wprowadzenie jednolitego, logicznego systemu oznaczeń. Elementy składowe to banery informacyjne zlokalizowane w charakterystycznych miejscach budynku, przy wejściu, węzłach komunikacyjnych, charakterystycznych punktach budynku (oddziały, jadalnia, świetlica, kaplica, pokoje pacjentów), schemat funkcjonalny budynku - w recepcji lub w miejscu występowania węzła komunikacyjnego. Poza tym tablice informacyjne, czyli informacja o sposobie poruszania się po budynku i oddziale (pokazujące kierunek ruchu), informacja o funkcji danego pomieszczenia. Bardzo ważnymi elementami dla osób 
starszych są zegar i kalendarz. Proponowane punkty umieszczenia tych elementów - recepcja, hall główny, świetlica, korytarz, pokoje pacjentów.

System informacji graficznej powinien być umieszczony w odpowiednich miejscach, między innymi przy recepcji (miejsce to jest bardzo ważnym punktem orientacyjnym i informacyjnym), przy węzłach komunikacyjnych. Układ informacyjny powinien być również odpowiednio zaprojektowany (tablice zawieszone na wysokości wzroku odbiorcy - od 120 do $160 \mathrm{~cm}$ nad poziomem posadzki, elementy bazowe projektu, czyli kolorystyka i dobór czcionki powinny być wybrane zgodnie $\mathrm{z}$ zasadami opisanymi wcześniej - maksimum trzy kolory, czcionka czytelna (maksimum dwa rodzaje), piktogramy mogą być elementem uzupełniającym, ułatwiającym rozpoznanie znaku.

\section{Realizacja potrzeb spolecznych starszych pacjentów w obrębie szpitala geriatrycznego}

Potrzeby społeczne, to takie potrzeby, których zaspokojenie wymaga istnienia i działania instytucji społecznych na rzecz zamierzonych celów. Potrzeby społeczne są dynamiczne, zatem podlegają ciągłym zmianom (Lisowski 2006). Obserwując zmiany związane ze wzrostem populacji osób starszych dostrzegamy konieczność zapewnienia im odpowiedniej opieki medycznej. Należy w związku z tym wystąpić z postulatami prezentującymi możliwości realizacji potrzeb społecznych osób starszych w szpitalach geriatrycznych czy określającymi standardy obowiązujące w szpitalach i oddziałach geriatrycznych. Mogą one przerodzić się w programy zaspokajania potrzeb, czyli źródła nowych norm i standardów społecznych.

Sposób realizacji potrzeb społecznych starszych pacjentów sprawdzono na podstawie analizy porównawczej szpitali geriatrycznych: Geriatric Centre Donaustadt w Wiedniu, w Austrii, Santa Rita Geriatric Centre w Ciutadella, Ille Baleares, w Hiszpanii, Mornington Centre zlokalizowanego w Victorii, w Australii, I'Hopital des Trois - Chene w Thonex w Szwajcarii, Centre Hospitalier Geriatrique Du Mont d'Or - Albigny Sur Saone we Francji oraz Szpitala Geriatrycznego w Katowicach, w Polsce.

Analiza porównawcza odnosiła się do zagospodarowania terenu i usytuowania budynku szpitala, do sposobu ukształtowania budynków - w szczególności do stref pacjentów, czyli pokoi oraz tzw. przestrzeni wspólnych. Powstałe schematy posłużyły do oceny realizacji potrzeb społecznych pacjentów i pozwoliły wyodrębnić kilka zasadniczych stref (Szewczenko 2013:162)). Strefy te wyodrębniono również badając polskie oddziały geriatryczne:

a. strefa pacjenta, czyli:

- sale chorych, 2- lub 3-osobowe o powierzchni minimum $18 \mathrm{~m}^{2} \mathrm{z}$ łazienką,

- łazienki i toalety, dostosowane do potrzeb osób z ograniczeniami ruchowymi, 
- przestrzenie społeczne jak świetlica, kąciki wypoczynkowe, kaplica,

b. strefa rehabilitacyjna - pomieszczenie do terapii ruchowej i elektroterapii,

c. strefa personelu lekarskiego:

- dyżurki pielęgniarskie, połączone z konsolami dozoru pielęgniarskiego,

- pokoje zabiegowe,

d. strefa pomocnicza:

- kuchnia oddziałowa,

- pomieszczenia gospodarcze (brudowniki),

e. strefa administracyjna.

Badania pozwoliły wyodrębnić potrzeby pacjentów szpitali geriatrycznych i wskazać sposoby kształtowania, tzw. przestrzeni wspólnych. Są one niezwykle istotnym elementem w przypadku oddziałów geriatrycznych, gdzie konieczne jest zapewnienie odpowiedniego klimatu społecznego - możliwości kontaktu z bliskimi, kontaktów społecznych pomiędzy pacjentami oraz wsparcia, nie tylko fizycznego, ale i psychicznego ze strony personelu medycznego.

Problemy ludzi starszych w sferze społecznej dotyczą przede wszystkim wrażenia alienacji i samotności. Seniorzy, nie nadążając za tempem współczesnego życia, zaczynają postrzegać siebie jako społecznie nieprzydatnych, co $\mathrm{w}$ połączeniu $\mathrm{z}$ częstym brakiem samoakceptacji powoduje tendencje do zaburzeń nastroju, stanów depresyjnych oraz zniecierpliwienia. $\mathrm{W}$ odpowiedzi na te problemy powinno się zapewnić osobom starszym jak najszerszy kontakt, zarówno z rówieśnikami, jak i osobami młodszymi. Taki kontakt pomaga oswoić się i zaakceptować obecną sytuację, a dzielenie się doświadczeniem generuje poczucie użyteczności. Równocześnie pacjenci mają prawo do zachowania intymności i wyciszenia.

Podczas pobytu w szpitalu bardzo ważny jest relaks i możliwość wyciszenia, skupienia. Pomaga to zadbać o stan psychiczny pacjenta, co wpływa na jego postawę w stosunku do choroby oraz tempo rekonwalescencji. Konieczne jest więc, żeby w placówkach zajmujących się osobami starszymi znalazły się pomieszczenia, które realizują te potrzeby.

Osoby starsze, szczególnie te z zaburzeniami mentalnymi, jak i fizycznymi wykazują często przywiązanie do otoczenia, w którym żyją. W sytuacjach, gdy niezbędna jest zmiana otoczenia ze względów zdrowotnych, np. pobyt w szpitalu, większość takich osób odczuwa dyskomfort, dezorientację, co wpływa negatywnie na stan zdrowia i tempo rekonwalescencji.

\section{Układ urbanistyczny szpitala geriatrycznego}

Zagospodarowanie terenu szpitala oraz jego lokalizacja mają ogromny wpływ na kondycję psychofizyczną pacjenta oraz jego samopoczucie. Jakość otoczenia decyduje o możliwości realizacji potrzeb społecznych pacjentów. 
Analizie porównawczej poddano takie elementy związane $\mathrm{z}$ zagospodarowaniem działki jak:

- otoczenie szpitala - ten element ma wpływ na możliwość powstania ogrodu przyszpitalnego, a także jego wielkość. Miejsce takie pozwala na spotkania $\mathrm{z}$ rodziną, $\mathrm{z}$ innymi pacjentami. Jest niezastąpionym miejscem relaksu i wyciszenia. Usytuowanie obiektu wśród terenów zielonych i wolnych od intensywnej zabudowy miejskiej pozwala na stworzenie dużego ogrodu przyszpitalnego (np. I'Hopital des Trois - Chene - kompozycja odśrodkowa). Lokalizacja wśród intensywnej zabudowy miejskiej nie daje takiej możliwości. Doskonałym przykładem tego typu sytuacji jest hiszpański szpital Santa Rita, który ze względu na swoje usytuowanie zamyka zieleń i tereny rekreacyjne w wewnętrznym atrium (kompozycja dośrodkowa).

- komunikacja - szpital powinien być dobrze skomunikowany z centrum miasta, w którym się znajduje - najlepiej jeśli jest położony w bliskim lecz nie bezpośrednim sąsiedztwie drogi krajowej. Tego typu lokalizacja pozwala pacjentom oraz innym użytkownikom szpitala (osoby odwiedzające, personel) na łatwe i szybkie dotarcie do obiektu. Równocześnie istotne jest, aby szpital nie znajdował się zbyt blisko głównych arterii komunikacyjnych, które mogą stać się uciążliwe (hałas, zanieczyszczenia),

- parkingi - obiekt szpitalny powinien posiadać odpowiednią liczbę miejsc postojowych przeznaczonych dla pacjentów, osób odwiedzających szpital, a także dla personelu. Oprócz rozmiaru parkingu ważna jest także jego lokalizacja - miejsca postojowe, szczególnie dla odwiedzających szpital, powinny być dobrze skomunikowane $\mathrm{z}$ wejściem głównym oraz odpowiednio oznakowane,

- możliwość rozbudowy obiektu - lokalizacja, wielkość działki oraz sposób ukształtowania szpitala mają wpływ na późniejsze losy obiektu. Możliwość rozbudowy szpitala daje większe szanse na wprowadzanie nowych funkcji $\mathrm{w}$ zależności od zmiennych w czasie potrzeb.

\section{Przestrzenie społeczne w szpitalach geriatrycznych}

Przestrzenie wspólne występujące w szpitalu pomagają realizować potrzeby pacjentów. Aby wyodrębnić pomieszczenia realizujące potrzeby społeczne pacjentów przeprowadzono analizę funkcjonalną wybranych, istniejących szpitali geriatrycznych.

Pomieszczenia służące do realizacji potrzeby kontaktu $\mathrm{z}$ innymi to:

- jadalnie stają się miejscami, gdzie pacjenci integrują się z odwiedzającymi oraz personelem - lokowane są często przy wejściach, stają się „sercem” budynku, 
- salony są strefami o charakterze wypoczynkowym w formie grupowej, gdzie relaks połączony jest $\mathrm{z}$ integracją społeczną. Realizowane często w formie pokoi telewizyjnych,

- świetlice (do zajęć warsztatowych) są pomieszczeniami wyposażonymi w stoliki, przeznaczone do pracy grupowej, ustawione w sposób sprzyjający rozmowom i wymianie doświadczeń.

Potrzeba relaksu i wyciszenia:

- kaplice - miejsca realizacji potrzeb związanych ze stanem duchowym,

- zieleń, czyli takie przestrzenie jak ogrody zimowe, tarasy, loggie - są miejscami, które zarówno umożliwiają relaks jak i aktywizują pacjentów (spacery, ruch), co sprzyja rekonwalescencji i powrotowi do zdrowia,

- pomieszczenia relaksacyjne, takie jak baseny, siłownie wspomagają kondycje fizyczną pacjenta - pomagają w kontaktach międzyludzkich, ale służą również wyciszeniu.

By zniwelować negatywne skutki pobytu w szpitalu, w nowym miejscu (potrzeba swobody w nowym otoczeniu) istotne jest:

- odpowiednie kształtowanie komunikacji w budynku - jej układ powinien być czytelny, jasny, prosty z odpowiednią informacją graficzną oraz punktami orientacyjnymi,

- dobre oznaczenie pomieszczenia recepcji, punktu informacyjnego oraz pomieszczenia rejestracji. Miejsca te powinny być widoczne $\mathrm{z}$ daleka, dobrze oświetlone ze względu na pacjentów, szczególnie tych z zaburzeniami mentalnymi, ale również ze względu na osoby odwiedzające.

- zaprojektowanie pomieszczeń o przeznaczeniu edukacyjno-rekreacyjnym takich jak salony czy świetlice. Są to miejsca nawiązywania nowych znajomości, które pozwolą na lepszą aklimatyzację pacjentów w nowym otoczeniu. Ważnymi elementami tej strefy są kolory, wyposażenie oraz wielkość pomieszczeń.

- branie pod uwagę materiałów wykończeniowych na podłogach, ścianach, sufitach - najlepiej naturalnych, np. drewna, odpowiedni dobór kolorystyki i oświetlenia oraz wyposażenia,

- prawidłowe zaprojektowanie i aranżacja pokoi pacjentów z zapewnieniem miejsca do samodzielnego zagospodarowania (np. zdjęciami).

\section{Analiza porównawcza pokoi w szpitalach geriatrycznych}

Samopoczucie pacjentów w czasie pobytu w szpitalu zależy przede wszystkim od ich pokoi. Pokój pacjentów powinien być projektowany z uwzględnieniem następujących czynników (Czyński 2008: 67-78):

- liczby łóżek w pokoju i wielkości pokoju (zagęszczenia),

- usytuowania łóżek w pokoju, 
- odległości między łóżkami,

- odległości łóżka od okna, drzwi, łazienki, wc, umywalki,

- sposobu funkcjonowania instalacji technicznych,

- ergonomii jego wyposażenia i przystosowania dla osób niepełnosprawnych ruchowo,

- ogólnych wrażeń estetycznych związanych z ukształtowaniem, kolorystyką, oświetleniem, umeblowaniem,

- widoku za oknem,

- kontaktu wzrokowego z korytarzem szpitalnym,

- kontaktu $\mathrm{z}$ innymi pacjentami.

Koncepcje projektowania pokoi szpitalnych sprawdzono na podstawie analizy porównawczej pomieszczeń znajdujących się szpitalach geriatrycznych: Geriatric Centre Donaustadt w Wiedniu, w Austrii, Santa Rita Geriatric Centre w Ciutadella, Ille Baleares w Hiszpanii, Mornington Centre zlokalizowanym w Victorii, w Australii oraz Szpitalu Geriatrycznym w Katowicach, w Polsce.

Przeprowadzona analiza porównawcza pozwoliła na stworzenie typów pokoi dwuosobowych, które ze względu na potrzebę kontaktu z innymi osobami wydają się najlepszym rozwiązaniem. Powstał model, w którym brano pod uwagę następujące potrzeby pacjentów szpitala geriatrycznego:

- potrzebę prywatności - terytorium wokół łóżka, niezbędne sprzęty (szafka), gradacja prywatności (parawany), intymność w kontaktach z bliskimi oraz $\mathrm{z}$ personelem medycznym,

- potrzebę personalizacji przestrzeni - indywidualizacja pokoju (szafka, możliwość zawieszenia zdjęcia, obrazka), potrzeba domowej atmosfery (naturalne materiały użyte do wykończenia pomieszczenia i umeblowania, odpowiednia kolorystyka i oświetlenie),

- potrzebę regulacji interakcji społecznych - możliwość swobodnego kształtowania relacji (parawany), możliwość zmiany miejsca (stoliki), ochrona przed uciążliwą obecnością innych osób (parawany),

- potrzebę bezpieczeństwa - potrzeba kontaktu wzrokowego z otoczeniem, ochrona przed wpływem stresów środowiskowych (hałas, przykre zapachy, nadmierne promieniowanie słoneczne).

\section{Podsumowanie}

Przedstawiona analiza przestrzeni wspólnych w szpitalach geriatrycznych pokazuje, że rozwiązania przestrzenne są zróżnicowane, ale generalnie odpowiadają na potrzeby użytkowników:

- w nowoczesnych szpitalach i ośrodkach opieki nad seniorami duży nacisk kładzie się na zapewnienie odpowiednio ukształtowanej przestrzeni społecznej przeznaczonej do użytku pacjentów, 
- niezwykle ważną rolę odgrywają przestrzenie zielone,

- pacjent geriatryczny powinien uczestniczyć w jak największej ilości aktywności zarówno fizycznych, jak i umysłowych. Zajęcia takie powinny odbywać się w odpowiednio przystosowanych do tego pomieszczeniach,

- ważnym aspektem przestrzennym są pomieszczenia przeznaczone do terapii zajęciowej, gdzie ludzie starsi mogą się spotkać np. z wolontariuszami,

- potrzebę prywatności powinno się realizować poprzez zapewnienie odpowiedniego terytorium wokół łóżka i zaopatrzenie w niezbędne sprzęty (szafki przyłóżkowe). W większości zbadanych szpitali rozwiązania zapewniają gradację prywatności - od intymnych rozmów z bliskimi po kontakty z personelem bądź współlokatorem,

- potrzeba personalizacji przestrzeni zapewniona została poprzez możliwość indywidualizacji pokoi (szczególnie pojedynczych). Projektanci przyjmowali rozwiązania w wyposażeniu, kolorystyce czy oświetleniu, które pomagały uzyskać domową atmosferę w pokojach,

- potrzeba regulacji intensywności interakcji społecznych była zazwyczaj realizowana poprzez możliwość swobodnego kształtowania relacji, możliwość zmiany miejsca i ochronę przed uciążliwą obecnością innych osób,

- potrzeba bezpieczeństwa realizowana była poprzez kontakt wzrokowy $\mathrm{z}$ otoczeniem oraz ochronę przed wpływem stresów środowiskowych.

\section{Bibliografia}

Bańka A. (2002), Społeczna psychologia środowiskowa, Wyd. Scholar, Warszawa.

Barcikowska M., Członkowska A., Derejczyk J. i wsp. (2006), Problemy zdrowia publicznego w kontekście starzenia się populacji Polski. Raport, „Postępy psychiatrii i Neurologii”, nr 3, s. 203-211.

Chalfont G. (2007), Design for Nature in Dementia Care, Jessica Kingsley Publish.

Czyński M. (2008), Terapeutyczna rola przestrzeni architektonicznej szpitala, Materiały VI Sympozjum. Architektura i Technika a Zdrowie, Wyd. Politechnika Śląska, Gliwice, s. 67-78.

Derejczyk J, Grodzicki T., Jakrzewska-Sawińska A, Jóźwiak A., Klich A. Wieczorkowska-Tobis K., (2005), Standardy świadczenia ustug medycznych specjalności geriatria, „Gerontologia Polska", nr 2, s. 67-83.

Lisowski A. (2006), Potrzeby społeczne i ich diagnozowanie, "Polityka społeczna", Warszawa.

Parke B. (2007), Physical Design Dimension of an Elder Friendly Hospital: An evidence - based practice review undertaken for the Vancouver Island Health Authority, Wyd. University of Victoria.

Szewczenko A., Weber A. (2013), Podstawowe wymagania funkcjonalno - przestrzenne dotyczace stacjonarnych oddziałów geriatrycznych $w$ aspekcie potrzeb indywidualnych osób starszych, „Gerontologia Polska, nr 4, s. 161-168.

Toutou, Haus E. (1994), Biologic Rhytms in Clinical labolatory medicine, Springer Verlag.

Tornington J.M., Tregenza P.R. (2007), Lighting for people with Dementia, „Lighting res. Technology", nr 39, s. 81-97. 
Iwona Dorota Benek, Anna Maria Szewczenko

\section{MEETING THE SOCIAL NEEDS OF GERIATRIC HOSPITAL PATIENTS}

Abstract. The article presents the functional factors of geriatric hospitals and their influence on the fulfillment of the patients' social needs.

It has been assumed that there exist a number of spatial determinants that may become important elements supporting the activity of the elderly staying in geriatric hospitals. As a result qualitative research has been performed on selected Polish and foreign examples in order to indicate recommended solutions connected with the location, the shaping of the building itself as well as selected functional zones used by the patients. Social needs of elderly patients have been discussed which is the basis for assuming specific design solutions.

Keywords: geriatric hospitals, interdisciplinary research, the elderly people. 